Chapter 9

\title{
Aflatoxin in Fish Flour from the Amazon Region
}

\author{
Ariane M. Kluczkovski and \\ Augusto Kluczkovski Junior \\ Additional information is available at the end of the chapter \\ http://dx.doi.org/10.5772/51948
}

\section{Introduction}

The Amazon region is well-known for biodiversity and nutritious food. The sustainable use of wildlife is considered strategically as an action for the conservation of the natural tropical environments and maintaining biodiversity [1]. The fish trade market, for example, comprises different countries and consumers with different intention of use, and requires a process chain of frozen fish as support. On the other hand, the Fish waste management has been of the problems with the greatest inpect on teh environment. Most of the waste is discarded or used in other fish products. Treated fish waste has found many applications among which the most important are animal feed, biodiesel/biogas, dietic products (chitosan), natural pigments (after extraction), food-packaging applications (chitosan), cosmetics (collagen), enzyme isolation, soil fertilizer and moisture maintenance in foods (hydrolysates)[2]. The muscle of some fish species with low fat, for example, can be useful in the flour production. In Brazil, the fish industries waste provides environmental pollution due to the inadequate disposable ways, in most of the cases. About $50 \%$ of the biomass produced by the industries is discarded along the process. Thus, there is an increasing interest for other ways of profitability of those wastes, since a high amount of fish protein has been lost [3]. With the increasing world population, it became necessary to search for alternative foods, to increase the demand and supply. These sources of food should be nutritious, have good sensory characteristics and be low cost, to achieve much of the population [4]. The alternative that has grown tremendously in the market is to concentrate the protein of raw materials. The protein concentrate which has a high nutritional value and has a low cost of raw material used, aims to provide a product with the human element constructor, no fat, avoiding the intake of saturated fats cause high cholesterol, obesity and other consequences negative health [3]. Thus, a more directed waste recovery of slaughtered animals can be used in the form of direct consumption by humans, or indirectly by means of the feeding [4]. This protein concen- 
trate product could be obtained by other sources of animals such as fish [5] and soy or nuts $[6,7]$. The fish flour is an alternative protein source for the natives of the Amazon region and came from the Indian culture. Beyond that, the fish flour is used as animal feed in some regions. The flour of the acari-bodó (Liposarcus pardalis) fish, for example, is called "piracui" and it is considered the "classic" fish flour. In the Tupi language, "piracuí" means fish dry fire, pounded in a mortar, grind him to powder, sifted, put into and kept in a smokehouse. The idea was born of conserving food for all the Indian tribes of the Amazon. At the time of low water (drought) had plenty of food (hunting and fishing). And at the time of the great waters (floods), food was difficult because the fish moved around. Thus was born the idea of storing food: game meat (boiling them with herbs that will retain for several days). The native long dominate technique resulting in dehydration of fish product known as piracuí. Only one type of fish derived from fish muscle, dried and shredded, which represents a major source of protein, average of $70 \%$ protein of optimum digestibility in the diet of some population especially the poor [8].The production involves an artisanal drying process, with the raw material of the fish waste or the whole meat from the fish. The flour is regularly sailed in a bulk in local markets of the Amazon region at the Amazon environmental conditions with temperature above $25^{\circ} \mathrm{C}$ and relative humidity ( $\mathrm{RH}$ ) above $70 \%$. In most of the markets it is sailed between other products. The illustration of the fish flour presentation is presented in Figure 1 ( $a$ and $b$ ).

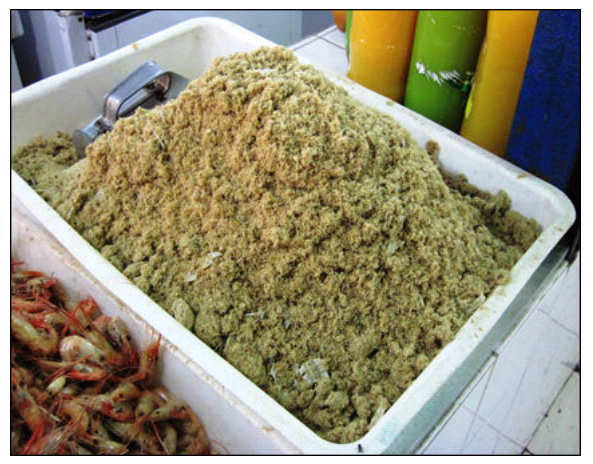

(a) Fish Flour (Piracuí) sold in the market

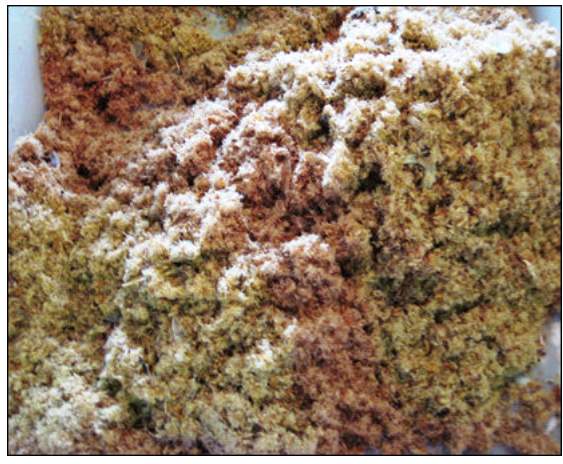

(b) Fish Flour (Piracuí)

Figure 1. Fish Flour (Piracuí) presentation

It is consumed as ingredient in the local cuisine or as a protein source. Some authors reported the final product proximate composition of flour and protein concentrate as described in Table 01.

The protein levels around 78\% from piracuí seems to be higher than other protein concentrate obtained from other fish ranging from 57.4 to $77.8 \mathrm{~g} \%$ [10]. The fish flour is sailed in common markets and there is no color or granulometry standard, since each artisanal pro- 
duction region has different procedures of process. It can be visible in the product the presence of bones and collagen fibers such as showed in Figure 2.

\begin{tabular}{|c|c|c|c|c|}
\hline \multicolumn{5}{|c|}{ Proximate Composition of fish products } \\
\hline & Peixotc & & Murueta $[10]^{b}$ & Romanelli\&Schmidt [11] \\
\hline Calories $^{d}$ & $356.8^{e}$ & $350.5^{f}$ & $3888.4-5015.9$ & - \\
\hline Moisture ${ }^{g}$ & 7.3 & 11.8 & $69.9-82.5$ & $2.4-3.8$ \\
\hline Proteing & 76.4 & 75.5 & $57.4-77.8$ & $36.8-63.4$ \\
\hline Lipids ${ }^{9}$ & 4.7 & 4.7 & $0.6-16.5$ & $22.2-52.5$ \\
\hline Ash ${ }^{9}$ & 9.4 & 6.5 & $8.1-20.2$ & $2.3-12.4$ \\
\hline
\end{tabular}

aSamples of piracui from Liposacus pardalis; ${ }^{\text {b }}$ Protein concentrate from nine different fish species (range); ' Samples of Viscera Flour from Caiman yacare ; ${ }^{d}$ Expressed in kcal; e Piracuí done by grilled fish; ${ }^{f}$ Piracuí done by cooked fish; ${ }^{9}$ expressed in $\mathrm{g} \%$.

Table 1. Proximate composition of fish and fish products samples according different authors.

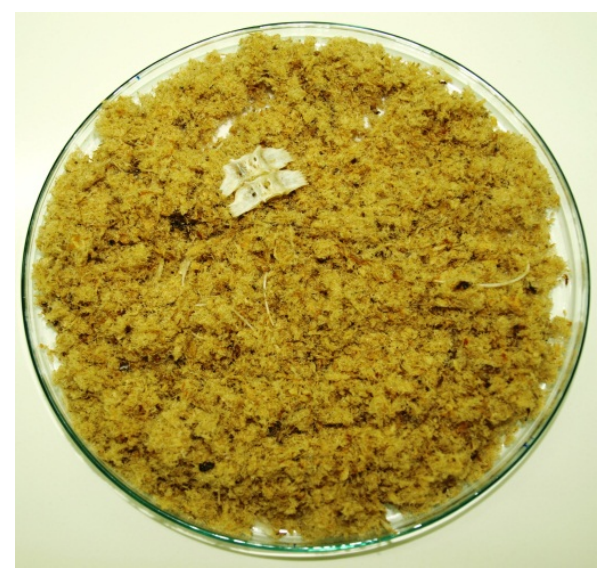

Figure 2. Small bones in Fish Flour (Piracuí)

The production of piracuí takes some stages and the flowchart is described in Figure 3. The fish or fish waste are washed and, the fish is eviscerated. They are cooked in an oven $\left(100^{\circ} \mathrm{C}\right)$ and Sodium Chloride $2 \%$ is added. Then, a stage of drying is applied with temperatures of 60 to $80^{\circ} \mathrm{C}$ for 50 to $60 \mathrm{~min}$. The material is cooled in room temperature and packaged in polyethylene bags and stored at room temperature.

The low water activity (aw) and moisture content $(m c)$ levels in the product can increase the stability and shelf life, because the flour does not require refrigeration or low temperatures of storage, and can be kept in the environmental conditions. This is an advantage of the fish 
flour for some Amazon communities, because they are geographically far from the power energy supplies to keep poultry food. On the other hand, some environmental conditions from the Amazon region, such as high temperature $\left(>30^{\circ} \mathrm{C}\right)$ and $\mathrm{RH}>80 \%$ associated to the poor safety conditions of the process can favor the contamination, especially by fungi that can be toxigenic, such as the mycotoxin producers [12]. The aflatoxin is one of those metabolic produced by some fungi strains with carcinogenic action to human beings and their level in food supply must be studied [13].

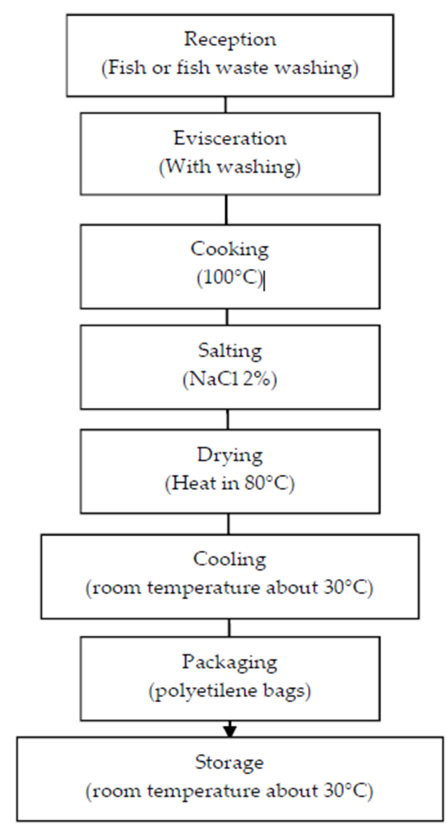

Figure 3. Flowchart of general Fish Flour Process

They have been reported, not only in nuts and vegetable products, but also in animal feed and meat products. Some aflatoxigenic moulds have been isolated from salted fish samples such as Candida spp., Rhodotorulla spp. and Aspergillus spp. [14]. Concerning the possibility of aflatoxigenic moulds in animal feed and to prevent contamination in the Amazon region consumers diet, a work was carried out in order to evaluate the presence of aflatoxin in fish flour samples from the Amazon Region a work was carried out concerning the evaluation of water activity $(a w)$, moisture content $(m c)$, aflatoxigenic fungi strains and total aflatoxin.

\section{Material and methods}

The total of 30 (thirty) samples (500g each) of fish flour from Brazil were collected from public markets at the Amazon region. The samples were sailed in a bulk. 
The methods of analysis were:

a. Aflatoxigenic moulds: the samples were prepared and examined according to the technique recommended by APHA [15]. The identification of isolated mould and yeast genera was carried out according to Pitt \& Hocking [16]. For the evaluation of aflatoxigenic strains, we used the method of incubation of strains from coconut agar (5-7 d, 26-28 $\mathrm{C}$ ) [17]. To the Aspergillus spp. strain, only that identified as A. flavus were tested. After incubation the colonies were observed in UV light. The fluorescence indicative of the presence of aflatoxins was observed at the reverse of the plate.

b. Total aflatoxin $\left(B_{1}+B_{2}+G_{1}+G_{2}\right)$ : the samples were analyzed by HPLC [18]. The Limit of Quantification (LOQ) was $0.95 \mu \mathrm{g} / \mathrm{kg}$. Five points were used to build an analytical curve, in order to obtain the correlation coefficient (R) values for LOD and LOQ. Each point corresponded to a mean of five injections of each extract. The recoveries for each aflatoxin $\left(B_{1}, B_{2}, G_{1}\right.$ and $\left.G_{2}\right)$ were: $91.0 ; 75.0 ; 95.0$ and $92.0 \%$, respectively.

Sample preparation: the samples were visually inspected in order to identify the presence of bones. The samples were finely ground in a mill (particle size $<100 \mu \mathrm{m}$ ) and homogenized;

Chemicals: aflatoxin standards and trifluoroacetic acid (TFA) were purchased by Sigma-Aldrich while acetonitrile, methanol (HPLC grade) and n-hexane were purchased by Nuclear;

Instrumentation: The HPLC operating conditions were as follows: Colum type and size: C18 Supelco; $25 \mathrm{~cm}$ x $4.6 \mathrm{~mm}$ id; 5 micron particle size; Temperature: room temperature 25C; Mobile phase: deionized water: acetonitrile:methanol:water (8:27:65) and the flow rate was fixed at $1.0 \mathrm{ml} \mathrm{min}{ }^{-1}$; membrane filter and degassed in an ultrasonic bath for 25 min prior to use;

Standards preparation: the aflatoxin $B_{1}, B_{2}, G_{1}$ and $G_{2}$ standards (1.0 $\mathrm{mg}$ of each aflatoxin) in capped amber bottles) were used to the working solutions were prepared according to the AOAC [19] procedure by injecting $1 \mathrm{ml}$ of acetonitrile into each vial to dissolve the aflatoxins.

Extraction and clean-up: $20 \mathrm{~g}$ of sample was extracted with $80 \mathrm{~mL}$ acetonitrile:water (9:1) mixture for $30 \mathrm{~min}$ by shaking under high speed and then filtered using a $\mathrm{N}^{\circ}$. 04 Whatman filter paper. A $1 \mathrm{~mL}$ portion of the filtrate was loaded on a multifunctional column and passed through at a flow rate of $2 \mathrm{~mL} / \mathrm{min}$. Then $1 \mathrm{~mL}$ of acetonitrile:water (9:1) was applied to the column for 5 times. The filtrates were combined and evaporated to dryness under nitrogen and the residue was used for the derivatisation.

Derivatization: a $100 \mu \mathrm{l}$ of the TFA solution and $300 \mu \mathrm{l}$ of n-hexane were added to the residue from the sample extracted or to the aflatoxin work standards, vortexed for $30 \mathrm{~s}$ and kept in the dark for 15 minutes in room temperature. Nine hundred microlitres of acetonitrile:water (9:1) was added to the vial and vortexed for $30 \mathrm{~s}$. The mixture was left to stand to allow the two layers to be separated. Twenty microlitres of the derivatized product (bottom layer) was injected into the HPLC column. 
3. Water activity (aw): was determined in triplicate in an Aqualab series 3TE instrument (Decagon, USA) at $25 \pm 0.1^{\circ} \mathrm{C}$;

(d)Moisture Content (mc): the $m c$ levels were determined by the gravimetric method [19];

\section{Results and discussion}

\subsection{Aflatoxigenic moulds}

All the samples (100\%) presented fungi growth. The Aspergillus spp. was identified in $85 \%$ of the samples and 15 isolated were obtained and tested concerning aflatoxin production as showed in Table 02. According to other authors, Aspergillus spp. was the most frequent strain reported in feed and fish products. Hassan et al. [14] also found levels of the presence of Aspergillus spp. (66.6\%). The Penicillium spp. was found in $43 \%$ of the samples and $90 \%$ of the isolated tested for aflatoxin production was negative.

\begin{tabular}{rcccc}
\hline Fungi Strains & $\begin{array}{c}\text { Incidence in the } \\
\text { samples (\%) }\end{array}$ & $\begin{array}{c}\text { Number of isolated } \\
\text { tested }^{a}\end{array}$ & \multicolumn{2}{c}{ Toxigenic Strains } \\
\cline { 3 - 4 } & 85 & 15 & $85 \%$ & Positive \\
\hline Aspergillus spp. & 43 & 10 & $10 \%$ & $90 \%$ \\
\hline
\end{tabular}

a Strains identified as Aspergillus flavus

Table 2. Fungi and aflatoxin production in fish four

In our work, from the Aspergillus spp strains identified as A. flavus, 85\% presented aflatoxin production as showed in Figure 4. Alinezhad et al. [20] reported A. flavus (60.66\%) isolated from feed ingredients as well as pellet feed. Among 37 A. flavus isolates, 19 (51.35\%) were able to produce $\mathrm{AFB}_{1}$ in the range of 10.2 to $612.8 \mu \mathrm{g} / \mathrm{g}$ fungal dry weight. The aflatoxigenic behavior with fluorescence was showed in Figure 4.

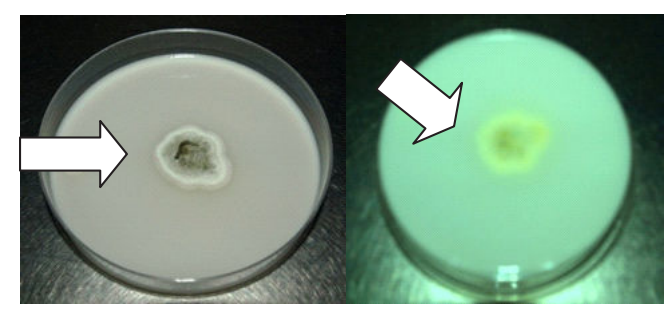

Figure 4. Aflatoxigenic behavior with fluorescence production from A. flavus from fish flour 
The presence of aflatoxigenic fungi strains can be explained by the environment contamination, since the product was disposable in room temperatures with no regards of hygienic standards. The Brazilian regulation does not require the fungi analysis in fish or fish products [21]. In the process of fish flour temperatures of $>60-80^{\circ} \mathrm{C}$ for $60 \mathrm{~min}$ are applied with the binomial time-temperature acting on the microbiological control. The fish flour is rich in protein and nutrients to be spoiled by aflatoxigenic fungi strains. Adding $\mathrm{NaCl} 2 \%$, during the process seems to not affect efficiently as a preservative factor to avoid fungi strains. In cured fish, for example, slight inhibition of mycelial growth and/or sporulation was recorded when isolates were cultured in basal medium containing $5 \%$ sodium chloride. On the other hand, the extent of inhibition increased with increasing salt concentrations, at $25 \%$ level, all the species had their growth completely inhibited [22].

\subsection{Aw, Mc and total aflatoxin}

The samples presented the following results with mean (range) described in Table 03. The (a) aw: 0.65 (0.64-0.70); (b) $m c$ : $15.5(10.0-20.8) \%$ and (c) total aflatoxin $\left(\mathrm{B}_{1}+\mathrm{B}_{2}+\mathrm{G}_{1}+\mathrm{G}_{2}\right): 10.5$ $(1.5-18.0) \mu \mathrm{g} / \mathrm{kg}$. The aflatoxin was found in $20 \%$ of the samples under the LOQ. All the positive samples were under the limit of the Brazilian regulation for animal feed of $50 \mu \mathrm{g} / \mathrm{kg}$ [23]. The 05 (five) positive samples for aflatoxin belong to the group of samples with $\mathrm{A}$. flavus isolated in the fungi test, and identified as aflatoxin producers. This fact, confirms the association between the presence of aflatoxigenic strains and the aflatoxin production in fish flour samples.

\begin{tabular}{ccccc}
\hline \multirow{2}{*}{$\begin{array}{c}\text { Number of } \\
\text { Samples }\end{array}$} & Aw & Mc \% & \multicolumn{2}{c}{ Total Aflatoxin $\boldsymbol{\mu g} / \mathbf{k g}^{\mathrm{a}}$} \\
\cline { 2 - 4 } & Mean (range) & Mean (range) & Positive samples & Mean (range) \\
\hline 30 & $0.65(0.64-0.70)$ & $15.5(10.0-20.8)$ & $05(20 \%)$ & $10.5(1.5-18.0)$ \\
\hline
\end{tabular}

Total aflatoxin $=B_{1}+B_{2}+G_{1}+G_{2}$

Table 3. Aw, Mc and Total Aflatoxin in fish flour from the Amazon region

The aflatoxin production in the fish flour could be affected by the levels of aw and mc. Those parameters have shown to allow the toxigenic fungi strains into the aflatoxin production, as showed in other dry food, such as nuts [24]. In previous work [25], the aw levels ranged from 0.1-0.90 and the microbiological stability of piracuí was showed at aw $<0.6$ if $m c$ will be below $10 \mathrm{~g} \%$. The levels of our findings of $m c$ were higher than $10 \%$, so these levels must be concerned, because in aw below 0.6, there was reported shortly halophilic bacteria growth. Our results, concerning the $m c$ levels were below $18.6 \%$, reported by Santos \& Freitas [26]. 


\section{Conclusions}

Despite the levels of aflatoxin in the samples below the limits of the Brazilian regulation for animal feed, the mycotoxin must be avoided. The studies in this matter are necessary, especially in areas such as the Amazon communities where the consumption of fish or fish products occurs $6 \mathrm{~d} /$ week, with $6.1 \mathrm{~g} / \mathrm{capital} / \mathrm{d}$ [27]. This data confirms that "piracuí" has an economic relevance [28]. Concerning the levels of aflatoxin found in the samples, it is necessary a work of good manufacture practices and safety storages conditions. The results of aw and $m c$ this research provide data for the study of materials that can be used as packaging for storage of piracuí due the product to be frequently traded in the Amazon region. Concerning the significance of the fish flour for the Amazon region consumers, other studies are necessary to evaluate other toxicological aspects and the risk analysis.

\section{Author details}

Ariane M. Kluczkovski* and Augusto Kluczkovski Junior

Federal University of Amazonas, Faculty of Pharmaceutical Sciences, Manaus, Am, Brazil

\section{References}

[1] Rodrigues, E. C., Bressan M.C., Vicente Neto, J., Vieira, J. O. , faria, P. B., Ferrão, S. P. B., Andrade, P. L. Quality and chemistry composition of commercial cuts of alligator swanpland meat (Cayman yacare). Ciênc. Agrotec. 2007, 3(2), 448-455.

[2] Arvanitoyannis, I.S. \& Kassaveti, A. Fish industry waste: treatments, environmental impacts, current and potential uses. International Journal of Food Science and Technology 2008, 43, 726-745.

[3] Camilo, A. G.; Fonseca, G. G.; Cavenaghi, A.D., Azambuja, S.P.H. Obtenção de concentrado proteico a partir de carne mecanicamente separada de pescado pintado. UFGD. MSc. 2011.

[4] Romanelli, P. F \& Schmidt, J. Study of the utilization of the pantanal alligator's viscera for meat four. Ciênc. e Tecn. de Alimentos, 2003, 23: 131 - 139.

[5] Souza, J. F., Bitencourt, N. N., Gomes, C. S.; Oliveira, J. K., Santos, R. M., Reis, I. A. O., Nunes, M. L. Nunes, Narain, N. Desenvolvimento e caracterização físico-química e sensorial de nuggets formulados com concentrado protéico de pescado - Marine Beef, Scientia Plena 2010, 6(3), 2-4.

[6] Meza, B. E., Verdini R. A., Rubiolo A.C. Effect of freezing on the viscoelastic behaviour of whey protein concentrate suspensions. Food Hydrocolloids 2010, 24, 414-423. 
[7] Gloria, M. \& Regitano-d'Arce, M. A .B. Concentrado e Isolado protéico de Torta de Castanha do Pará:Obtenção e Caracterização Química e Funcional. Cienc. Tecnol. Aliment 2000, 20 (2), 240-245.

[8] Peixoto, C. Produção e estabilidade durante a estocagem de concentrado proteico de peixe (piracui) de acari-bodo, Pterygoplichtys multiradiatus, hancok (1828) e aruana Osteoglossum bicirrhosum (Vandelli, 1829). MSc. INPA/UFAM; 110p; 1999.

[9] Marueta, J. H. C., Del Toro, M. de L. A. N. \& Carreno, F. G. Concentrates of fish protein from by catch species produced by various drying processes. Food Chemistry 2007, 100 705-711.

[10] Pacheco, A. M. \& Scussel, V. M., 2006. Effects of processing and factory storage on aflatoxin contamination of in-shell Brazil nuts. Proceedings of the $9^{\text {th }}$ International Working Conference on Stored Product Protection, 159-164.

[11] IARC. International Agency of Research on Cancer. Evaluation of carcinogenic risks to humans: some naturally occuring substances: aromatic amines and mycotoxins. Lyon.. IARC Monographs, 56. p. 245-39, 1997.

[12] ] Hassan, A. A.; Hassan, M. A., Howayda, M. E., El Ahl, R. M. H. Abd El-Dayem, R.H.. Detection of aflatoxigenic moulds isolated from fish and their products and its public health significance. Nature and Science 2001, 9 (9), 106- 114.

[13] APHA. American public health association. 2001. Compendium of met. for the mic. exam. of foods . $4^{\text {th }}$ Ed. American Public Health Association, Washington, DC.

[14] Pitt, J.I. and Hocking, A.D. 1999. Fungi and Food Spoilage. 2 ed. Aspen Publishers, Maryland, USA. 593p.

[15] Davis, N., Iyer, S., Diener, U. Improved method of screening for aflatoxin with a coconut agar medium. App. and Env. Microbiology 1987, 53:7, 1593-1595.

[16] Khayoon, W. S., Saad, B., Yan, C. B., Hashim, N.H., Ali, A. S. M., Salleh, M. I., Salleh, B. Determination of aflatoxins in animal feeds by HPLC with multifunctional column clean-up. Food Chemistry 2010, 118, 882-886.

[17] AOAC. Association of Official Analytical Chemists. 2005. Official methods of analysis of AOAC international (17 th ed.). Gaithersburg, MD, USA:AOAC International.

[18] Alinezahd, S.; Tolouee M.; Kamalzadeh A.; Motalebi A. A., Nazeri M., Yasemi M., Shams-Ghahfarokhi M., Tolouei R., Razzaghi-Abyaneh M. Mycobiota and aflatoxin B1 contamination of rainbow trout (Oncorhinchus mykiss) feed with emphasis to Aspergillus section Flavi. Iranian Journal of fisheries 2011, 10(3), 363-374.

[19] Brazil. Ministerio da Saude, ANVISA. RDC 12, 02/01/2001.

[20] Diyaolu, S. A. \& Adebajo. L. O. Effects of sodium chloride and relative humidity on growth and sporulation of moulds isolated from cured fish. Food Nahrung 1994, 38(3), 311-317. 
[21] BRASIL. Ministério da Agricultura. Portaria n. 07, de 09 de novembro de 1988. Estabelece os padrões mínimos das diversas matérias primas empregadas na alimentação animal. Diário Oficial da União, Poder Executivo, Brasília, DF, 09 de novembro de 1988.

[22] Arrus, K., Blank, G., Clear, R., Holley, R.A. Aflatoxin production by Aspergillus flavus in Brazil nuts. J. of Stored ducts Research 2005, 41, 513-527.

[23] Lourenço, L. F. H., Santos, D. C., Ribeiro, S.C.A., Almeida H., Araujo, E.A.F .Study of adsorption isoth.erm and microbiological quality of fish meal type "piracuí" of AcariBodo (Liposarcus pardalis, Castelnau, 1855). Procedia - Food Science 2011, 1, 455-462.

[24] Santos, J. R. C. \& Freitas, J. A. Characteristics and quality of a piracuí fish derived product Rev. ciênc. agrár. 2004, 41, 25-46.

[25] Cerdeira, R.G.P. Fish consumption and others food itens by the riverine population of the Lago grande de Monte Alegre, PA-Brazil, Acta Amazonica 1997, 27(3):213-228.

[26] Almeida, J.C. Economic evaluation of protein concentrate production by Amazon fish. MSc. INPA, 165 p. 2009. 